\title{
Variation in Soil Fungal Composition Associated with the Invasion of Stellera chamaejasme L. in Qinghai-Tibet Plateau Grassland
}

\author{
Wei He ${ }^{1,2, *,+} \mathbb{D}$, Andrew Detheridge ${ }^{3, \dagger}$, Yongmei Liu ${ }^{4}$, Lei Wang ${ }^{4}$, Haochen Wei ${ }^{5}$, \\ Gareth W. Griffith ${ }^{3}$, John Scullion ${ }^{3, *}$ and Yahui Wei ${ }^{1}$ (D) \\ 1 Key Laboratory of Resource Biology and Biotechnology in Western China, Ministry of Education, College of \\ Life Sciences, Northwest University, Xi'an 710069, China; weiyahui@nwu.edu.cn \\ 2 School of Chemical Engineering, Northwest University, Xian 710069, China \\ 3 Institute of Biological, Environmental and Rural Sciences, Aberystwyth University, Aberystwyth SY23 3FL, \\ UK; andrew.detheridge1@virgin.net (A.D.); gwg@aber.ac.uk (G.W.G.) \\ 4 College of Urban and Environmental Science, Northwest University, Xi'an 710069, China; \\ liuym@nwu.edu.cn (Y.L.); montez@nwu.edu.cn (L.W.) \\ 5 Research School of Biology, Australian National University, Canberra, ACT 2601, Australia; \\ haochen.wei@anu.edu.au \\ * Correspondence: hewei.scu@gmail.com (W.H.); jos@aber.ac.uk (J.S.); \\ Tel.: +86-2988302199 (W.H.); +44-1970622304 (J.S.) \\ + These authors contributed equally to this work.
}

Received: 18 October 2019; Accepted: 15 November 2019; Published: 20 November 2019

\begin{abstract}
Stellera chamaejasme L. is the most problematic weed in China's grasslands. Its root exudates affect co-occurring plants and thus may also affect soil fungi. Soils $(0-20 \mathrm{~cm}$ depth $)$ on two adjacent sites, one invaded the other uninvaded, were compared for a range of physiochemical parameters and by DNA sequencing of fungal communities. At the invaded site, relationships between S. chamaejasme abundance, soil physiochemical factors, and fungal communities were further investigated to determine whether these relationships corroborated conclusions on the basis of site differences that could be translated into functional variation. Results showed that the invaded soils had lower N, P, organic matter, fungal alpha diversity, and relative abundance of arbuscular mycorrhizal fungi (AMF), but greater abundance of pathogenic fungi. Organic matter and $\mathrm{P}$ were the edaphic factors most strongly linked to site differences in total fungal communities. Within the invaded site, organic matter rather than S. chamaejasme cover was closely linked to total fungal composition. However, on this site, a number of fungal species that had various ecological functions and that differentiated the two sites were related to $S$. chamaejasme cover. This study indicates that lower fertility soils may be more susceptible to invasion by S. chamaejasme. Although the influence of S. chamaejasme on total fungal community composition was limited, there was evidence of effects on particular fungal species. Further research is needed to determine whether these effects influence S. chamaejasme invasiveness.
\end{abstract}

Keywords: Stellera chamaejasme L.; soil fungal community; soil physiochemical parameters; invasion; amplicon sequencing

\section{Introduction}

Stellera chamaejasme L. (Thymelaeaceae) is a native perennial herbaceous plant of grasslands in China. Its remarkable acclimation ability enables it to occupy a wide range of grassland types and climates, spanning the northeast to the southwest of China [1]. In the grasslands of northern and 
western China, it has become an increasingly common weed [2]. It causes a deterioration of the grazing resource due to its unpalatability to herbivores and has become the most problematic weed in China's grasslands [3], threatening the viability of pastoral farming in affected regions. Once established, it tends to persist in part due to its avoidance by grazing animals.

S. chamaejasme is unusual in being an indigenous invasive weed and its expansion in grasslands across China has been attributed to several factors. Poor grassland management and subsequent degradation creates opportunities for invasion [4]; for example, excessive grazing has been found to favour establishment of the species [5]. Climate warming may also favour this species [6], as it can access reserves of moisture at soil depths greater than the grasses against which it competes [7]. S. chamaejasme also has deeper taproots compared to other grassland species.

Allelochemicals from S. chamaejasme roots such as umbelliferone, mesoneochamaejasmin A, and neochamaejasmin B enhance its competitive nature and broad ecological adaptability [8]; in this regard, there is clear evidence of such chemicals inhibiting germination and/or growth of a range of grassland species $[2,9,10]$. Invasive plants such as $S$. chamaejasme often induce positive feedbacks from soil biotic and abiotic properties that facilitate their expansion. These interactions may contribute to changes in soil fertility. For example, Sun et al. [11] found differences in C and $\mathrm{N}$ cycling between S. chamaejasme patches and adjacent between-patch soils; patches had higher organic contents, microbial biomass and respiration, and nitrate levels. They attributed these differences to an increased amount and $\mathrm{N}$ content of litter produced by $S$. chamaejasme, due to reduced herbivory and deeper rooting habit improving nutrient uptake.

For exotic invasives, their uncontrolled spread is postulated to result from release constraints of soil microbial populations in their native areas and positive feedback effects on soil microbes, which further inhibit the success of indigenous members of the plant community [12]. Such effects have been demonstrated in soil sterilisation experiments [13-15]. In some cases, it has been possible to identify which soil microbes are affected, for example, the inhibition of ectomycorrhizal fungi in North American woodlands invaded by the exotic non-mycorrhizal herb Alliaria petiolata [16]. More often, however, general changes in soil microbial populations are reported, for example by the molecular analysis of fungal populations in either plant roots [17] or bulk soil [18-21]. More recent investigations have deployed DNA metabarcoding via NextGen sequencing, for example, to investigate the effect of invasive Centaurea stoebe, Euphorbia esula, and Bromus tectorum in prairie grasslands on soil fungal and bacterial communities [22]. DNA metabarcoding offers the potential to identify at species level which components of the microbial community are altered by weed invasion.

To date, much of the research on S. chamaejasme has focused on the role of allelopathic impacts on its competitive strengths (e.g., [2]). Some studies have surveyed the bacterial $[23,24]$ and fungal $[25,26]$ communities associated with the rhizosphere and tissues of S. chamaejasme. However, the focus of these studies did not extend to analyses of bulk soil and consideration of whether microbial communities may facilitate or be altered by the spread of this plant in alpine grassland habitats. Evidence that chemicals from S. chamaejasme have activity against phytopathogenic fungi [27] suggest at least the potential for it to directly alter soil fungal communities. Sun et al. [11] suggested that $S$. chamaejasme alters the soil nutrient status, and, further, that this is an indirect mechanism by which $S$. chamaejasme could impact fungal communities. However, it is open to question whether the invasive plants alter edaphic properties and fungal communities or vice versa, given that no controlled experiment has been performed so far. Cryptically, S. chamaejasme plants do not grow into the mature stage under laboratory conditions. Therefore, in this study, by employing a large-scale sampling strategy, we aimed to answer the following questions:

(1) Do soil fungal communities and edaphic properties differ between S. chamaejasme invaded and uninvaded sites?

(2) Does S. chamaejasme abundance or edaphic conditions explain variations in fungal communities?

(3) Are there differences in functional groups or particular fungal species that might relate to the presence of S. chamaejasme? 
Here, we investigated fungal communities and key physiochemical properties in bulk soils. We compared fungal communities and associated soil properties on adjacent invaded and uninvaded grassland under similar management. Where site differences in fungal communities and soil physiochemical properties were indicated, their relationships with variations in density of cover of $S$. chamaejasme were investigated on the invaded site to establish whether site differences potentially attributable to $S$. chamaejasme were corroborated by trends within the invaded site.

\section{Materials and Methods}

\subsection{Experimental Sites}

Two adjacent sites in Qilian County, Qinghai Province, China $\left(38^{\circ} 03^{\prime} 9.43^{\prime} \mathrm{N}, 100^{\circ} 30^{\prime} 14.71^{\prime \prime} \mathrm{E}\right)$ were selected for the study on the basis of their similar management, topographical characteristics, and close proximity $\left(2.8 \mathrm{~km}\right.$ ) (Figure 1). Average elevation is $3169 \mathrm{~m}$. Mean annual temperature is $1^{\circ} \mathrm{C}$, but in July average temperature may exceed $14{ }^{\circ} \mathrm{C}$ Annual precipitation is $420 \mathrm{~mm}$, with $81 \%$ of this precipitation occurring between June and September [28]. The soil type is leptosol (FAO, Harmonized World Soil Database v 1.2) and the grassland is described as alpine meadow $[29,30]$. On the 'uninvaded' site $\left(13,000 \mathrm{~m}^{2}\right)$ S. chamaejasme was absent, whereas on the invaded site $\left(23,000 \mathrm{~m}^{2}\right)$ it was present at varying densities. Information provided by local farmers indicated that $S$. chamaejasme first appeared around 20 years prior to this investigation and that its coverage had slowly increased on the invaded site.

Vegetation recording and soil sampling were undertaken at 50 and 25 locations in the invaded and uninvaded sites, respectively, on the basis of systematic (approximately $20 \times 20 \mathrm{~m}$ ) grids. Between-site comparisons used 25 randomly selected data points from the invaded site. In order to increase the sensitivity of investigations into relationships between $S$. chamaejasme abundance and soil parameters on the invaded site, the full dataset was used for this aspect of the investigation. Vegetation was surveyed (total cover to $1 \%$, and cover and number of S. chamaejasme) and soil samples were taken over the period of 15-17 July 2015, during the flowering season of S. chamaejasme. Significant rainfall occurred in the week prior to fieldwork. Plant coverage was imaged in $1 \mathrm{~m}^{2}$ quadrats located on a grid sampling scheme, then converted to percentage coverage of S. chamaejasme after normalization. As the focus of the study was on S. chamaejasme, the cover of other species was not recorded; for these species, only presence and general abundance was noted. Plant species common in both sites included Agropyron cristatum L., Bupleurum falcatum L., Potentilla multifida L., Kobresia myosuroides (Vill.) Fiori, Poa calliopsis Litv. ex Ovcz, and Gentiana leucomelaena Maxim. Agropyron cristatum L. and Kobresia myosuroides (Vill.) Fiori. were the dominant species on both sites. The invaded site included in addition minor occurrences of Medicago ruthenica (L.) Ledebour, Oxytropis falcata Bunge, Echinochloa caudata Roshev., and Lobularia maritima L., as well as S. chamaejasme. The uninvaded site vegetation also included Taraxacum mongolicum and Delphinium caeruleum [31].

\subsection{Main Sampling and Analyses}

Three soil cores ( $20 \mathrm{~cm}$ depth, $5 \mathrm{~cm}$ diameter) were taken at each vegetation quadrat location and bulked for soil and fungal analyses. The soil corer was thoroughly cleaned, initially with water then with $75 \%$ ethanol, between each sampling location to avoid contamination. Samples were kept at $4{ }^{\circ} \mathrm{C}$ and transferred to the laboratory within $48 \mathrm{~h}$. Subsamples were either frozen at $-80^{\circ} \mathrm{C}$ until DNA extraction or air dried for chemical analyses.

Soil chemical analyses focused on total nutrient contents rather than more transient measures of available nutrients. Soil physiochemical properties were measured as by Bao [32], total $\mathrm{N}$ by the Kjeldahl method, total $\mathrm{K}$ by NaOH fusion-flame photometry, total $\mathrm{P}$ by $\mathrm{NaOH}$ fusion-Mo/Sb colorimetry, and soil organic matter $(\mathrm{OM})$ by dichromate oxidation- $\mathrm{FeSO}_{4}$ titrimetry. Soil $\mathrm{pH}$ was measured in a 1:2.5 soil:water suspension. Gravimetric soil moisture contents were measured immediately on return to the laboratory by drying at $105^{\circ} \mathrm{C}$. 

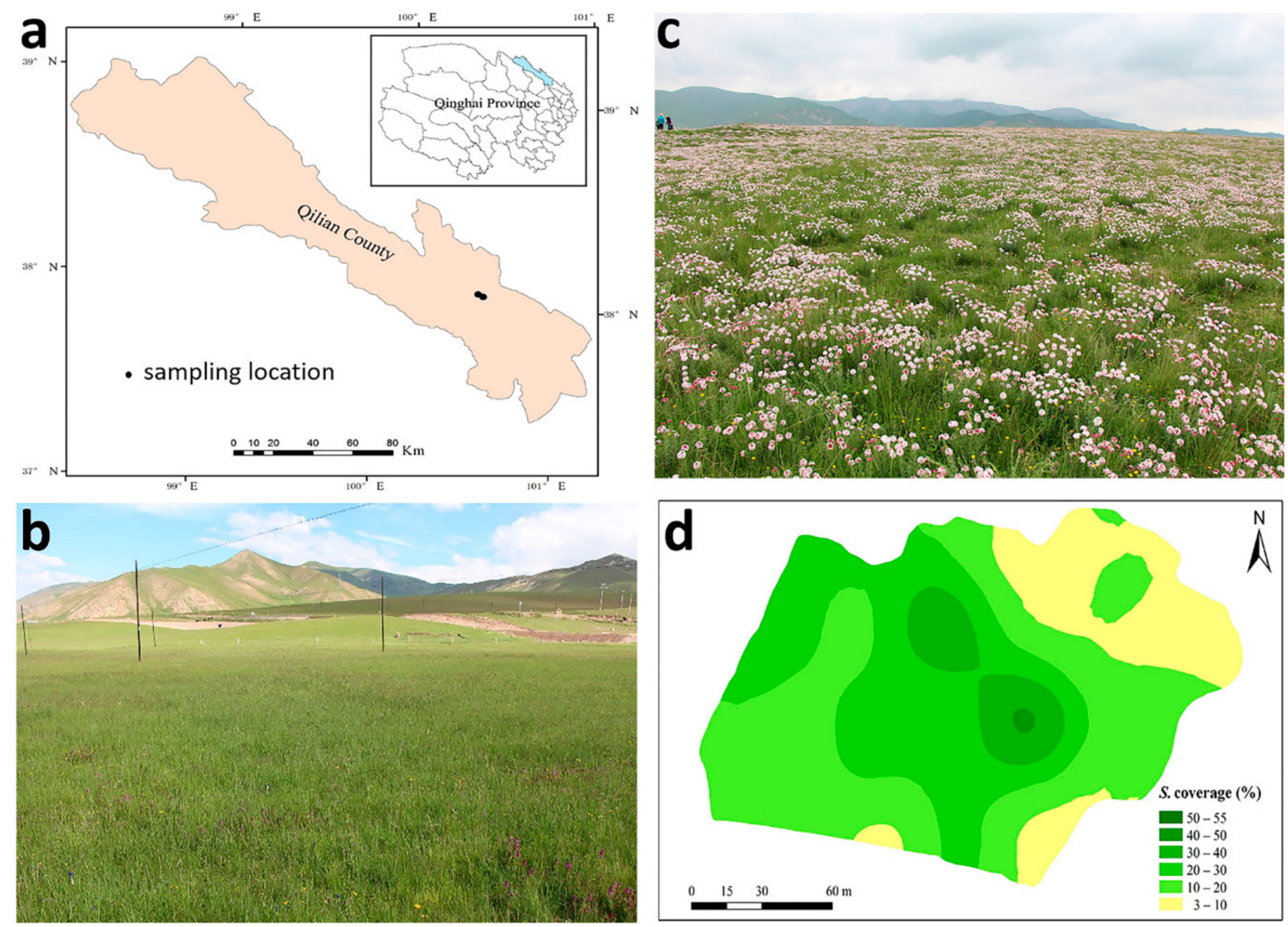

Figure 1. (a) Sampling location in Qilian County on the Qinghai-Tibetan Plateau; $(\mathbf{b}, \mathbf{c})$ uninvaded and invaded sites; and (d) S. chamaejasme coverage on the invaded site.

Soil DNA was extracted from $250 \mathrm{mg}$ of each soil sample using an MO BIO Power Soil DNA Isolation Kit (Qiagen, Hilden, Germany) according to the manufacturer's instructions. Polymerase chain reaction (PCR) amplification of the ITS1 (Internal Transcribed Spacer) region of the rRNA (ribosomal RNA) locus was undertaken using the primers ITS1F ( $5^{\prime}$-CTTGGTCATTTAGAGGAAGTAA- ${ }^{\prime}$ ) and ITS2R (5'-GCTGCGTTCTTCATCGATGC-3') linked with barcodes. The PCR reaction $(25 \mu \mathrm{L})$ contained the following reagents: $10 \times$ PCR Buffer $2.5 \mu \mathrm{L}, 10 \mathrm{mmol} / \mathrm{L}$ dNTP (deoxy-ribonucleoside triphosphate) $1 \mu \mathrm{L}$, forward and reverse primers $(10 \mu \mathrm{mol} / \mathrm{L})$ each of $1 \mu \mathrm{L}$, soil DNA template $(50 \mathrm{ng} / \mu \mathrm{L}) 2 \mu \mathrm{L}, 5 \mathrm{U}_{\mu} \mathrm{L}^{-1}$ Taq DNA polymerase $0.4 \mu \mathrm{L}$, and double-distilled water $\left(\mathrm{ddH}_{2} \mathrm{O}\right) 17.1 \mu \mathrm{L}$. PCRs were performed at $95^{\circ} \mathrm{C}, 5 \mathrm{~min} ; 95^{\circ} \mathrm{C}, 30 \mathrm{~s} ; 50{ }^{\circ} \mathrm{C}, 30 \mathrm{~s} ; 72{ }^{\circ} \mathrm{C}, 40 \mathrm{~s}$ ( 30 cycles); $72{ }^{\circ} \mathrm{C}, 7 \mathrm{~min}$; and $4{ }^{\circ} \mathrm{C}$ hold. PCR products were purified using MoBio UltraClean PCR Clean-Up Kit (Qiagen) and an aliquot of clean PCR product for each sample was sent for sequencing. Sequencing was performed on an Illumina 2500 HiSeq (Illumina, San Diego, CA, USA) by the Beijing Biomarker Biotechnology Co., Ltd. (Beijing, China), who ligated sequencing adapters and pooled samples in equimolar concentrations for library formation.

\subsection{Data Analysis}

Differences in soil chemistry and moisture between the uninvaded and invaded sites were evaluated by ANOVA (one-way analysis of variance). Where fungal and physiochemical indices differed significantly between sites, data from within the invaded site were further investigated to assess plant-fungi-soil interrelationships.

Sequence data were processed as detailed in Detheridge et al. [33]. A total of 71 soil samples were analysed, with DNA recovered from all 25 samples on the uninvaded site and from 46 (extraction was unsuccessful in four instances) on the invaded site. Comparison between sites was on the basis of processed data from randomly selected 25 samples in the invaded group against all 25 samples from the uninvaded site. To investigate associations between $S$. chamaejasme coverage, soil properties, and 
fungal diversity, the analyses were performed on all the 46 invaded site samples from which DNA was extracted.

Following DNA metabarcoding of the ITS1 region between the SSU (small subunit) and 5.8S rRNA genes, the resulting sequences were assigned to taxa using the RDP (Ribosomal Database Project) Naïve Bayesian classifier [34] against the UNITE v6 database [35] supplemented with non-fungal sequences, so that non-fungi could be identified. A sequence for S. chamaejasme (NCBI (National Center for Biotechnology Information) accession number MG516523) was also included to identify samples where sequences belonging to this species occurred. Ecological function of fungi was assigned to each taxon (where identified) at species, genus, or family level using the Funguild database [36]. Sequence data have been submitted to the European Nucleotide Archive with reference number PRJEB29489. Shannon $\left(-\sum_{i=1}^{S} P_{i} \ln P_{i}\right.$ where $P_{i}=$ relative proportion of the $i$ th taxa) and Simpson $\left(1 / \sum_{i=1}^{S} P_{i}^{2}\right)$ diversity indices were calculated for each quadrat.

An unconstrained ordination technique (principal coordinate analysis-PCO) was used against the Bray-Curtis distance matrix. Permutation multivariate analysis of variance (PERMANOVA) was used to determine overall significant to compare total fungal communities. Percentage abundance percentage data were transformed (square root) to reduce the effect of dominant taxa and Bray-Curtis distance matrices were calculated. The PERMANOVA used default settings with Monte Carlo $p$-values calculated on the basis of 9999 unrestricted permutations. The influence of environmental data on fungal communities was investigated by distance-based redundancy analysis (dbRDA) [37]; predictor variables were normalised before analysis. Analysis of similarity (ANOSIM) determined the extent of divergence in communities at site level and similarity percentages (SIMPER) indicated taxa contributing most to these site differences. The above analyses were performed in PRIMER 6 and PERMANOVA+ (versions 6.1.12 and 1.0.2 respectively; Primer-E, Ivybridge, United Kingdom). Analyses of variance (ANOVA) were performed in Sigma Plot (version 12.5, Systat Software Inc., San Jose, CA, USA); data normality (Shapiro-Wilk) and equality of variance (Levene's) were tested prior to ANOVAs. Post-hoc differences were tested using Fisher's least significant difference (LSD).

\section{Results}

Total vegetation cover was similar on the two sites (uninvaded $88.5 \%$; invaded $87.6 \%$ ), with an average of $19.8 \% \mathrm{~S}$. chamaejasme cover at the invaded site (across the 50 quadrats). S. chamaejasme cover was highly variable, ranging from $3 \%$ to $55 \%$ with a mean of 17.5 plants $/ \mathrm{m}^{2}$. S. chamaejasme was not observed in the uninvaded site (Figure 1) but sequence data showed that $S$. chamaejasme DNA was present in soils at seven quadrats $(28 \%)$ from the uninvaded site compared to $33 \%$ of quadrats from the invaded site. Thus, S. chamaejasme was cryptically present in the uninvaded site, likely as seed or small seedlings.

\subsection{Soil Physiochemical Properties}

Uninvaded soils had higher total P, N, and organic contents (Table 1); in contrast, total K was lower in uninvaded soils. The C:N ratio of uninvaded soils was significantly higher than for soils on the invaded site. Soil $\mathrm{pH}$ and moisture was similar, but the latter result may have been affected by rainfall prior to sampling.

Table 1. Total soil nutrient and moisture contents (mean \pm standard error, $n=25$ per site).

\begin{tabular}{cccc}
\hline & Uninvaded & Invaded & $p$-Value \\
\hline$\% \mathrm{~K}$ & $1.96 \pm 0.016$ & $2.02 \pm 0.017$ & 0.0487 \\
$\% \mathrm{P}$ & $0.06 \pm 0.001$ & $0.05 \pm 0.002$ & 0.0042 \\
$\% \mathrm{~N}$ & $0.29 \pm 0.043$ & $0.22 \pm 0.015$ & 0.0009 \\
$\% \mathrm{OM}$ & $5.72 \pm 0.217$ & $4.02 \pm 0.287$ & 0.0002 \\
$\mathrm{C}: \mathrm{N} \mathrm{ratio}$ & $11.4 \pm 0.081$ & $10.7 \pm 0.089$ & $<0.0001$ \\
$\% \mathrm{H}_{2} \mathrm{O}$ & $26.8 \pm 0.816$ & $28.2 \pm 0.514$ & 0.136 \\
$\mathrm{pH}$ & $7.85 \pm 0.061$ & $7.98 \pm 0.082$ & 0.176 \\
\hline
\end{tabular}

$\mathrm{C}=$ carbon, $\mathrm{N}=$ nitrogen, $\mathrm{P}=$ phosphorous, $\mathrm{K}=$ potassium, $\mathrm{OM}=$ organic matter, $\% \mathrm{H}_{2} \mathrm{O}=$ gravimetric moisture. 


\subsection{Fungal Populations}

The mean number of sequences obtained per sample from DNA metabarcoding was 58,838 (range 17,799-279,702). After clustering, there were 3310 operational taxonomic units (OTUs) in total across all 71 quadrats where DNA was recovered.

Rarefaction was to the sample with the least number of sequences $(17,800)$. After rarefaction, clustering (excluding those with $<2$ sequences) and classification, the mean fungal sequence number per sample was 16,325; non-fungal sequences (929) were not included in any further analyses.

The PCO plot (Figure 2) separated the fungal communities in the uninvaded and S. chamaejasme invaded site soils; the primary axis explained only $12.1 \%$ of the variation in these communities. The PERMANOVA main test was significant ((Pseudo- $F=7.9509, p=0.001, p(\mathrm{MC})=0.001)$, as was the ANOSIM test $(r=0.509, p=0.001)$.

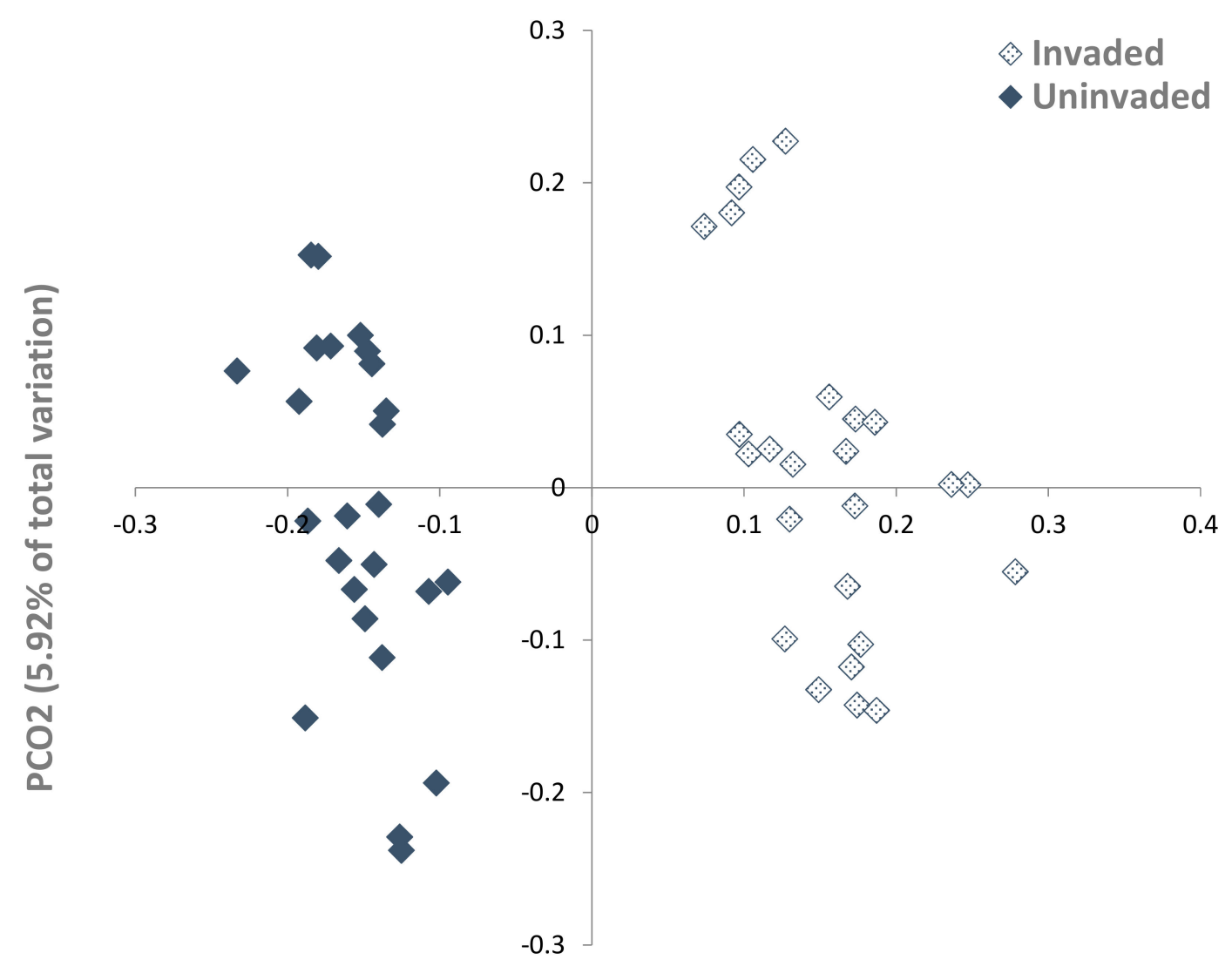

\section{PCO1 (12.1\% of total variation)}

Figure 2. Principal coordinate ordination (PCO) of soil fungal communities in invaded and uninvaded grasslands ( 25 samples each site), showing a clear separation between the two communities (permutation multivariate analysis of variance (PERMANOVA) Pseudo- $F=7.9509, p=0.001$; analysis of similarity (ANOSIM) $r=0.509, p=0.001$ ).

Both the fungal OTU count $(p<0.001)$ and the Shannon index $(p=0.031)$ were higher in the uninvaded site soils (Table 2). The relative abundances of three fungal phyla differed between sites; Glomeromycota (synonymous with AMF), Ascomycota, and Zygomycota (dominated here by species within the order Mortierellales). Ascomycota were more dominant on the invaded site than the uninvaded site $(p<0.001)$, whereas the reverse was the case for Zygomycota $(p=0.034)$ and Glomeromycota, $(p<0.001)$ which were more abundant on the uninvaded site. 
Table 2. Population diversity indices and percentage of fungi operational taxonomic units (OTUs) identified to phylum level (mean \pm standard error). Significant differences $(p<0.05$ on the basis of ANOVAs) between the uninvaded and the invaded site were indicated by different letters $(n=25$ per site).

\begin{tabular}{ccc}
\hline & Uninvaded & Invaded \\
\hline Population diversity indices & & \\
\hline OTU Count & $265 \pm 8.38 \mathrm{a}$ & $192 \pm 7.08 \mathrm{~b}$ \\
Inverse Simpson Index (OTU) & $21.36 \pm 1.72$ & $17.58 \pm 1.42$ \\
Shannon Index (OTU) & $3.85 \pm 0.06 \mathrm{a}$ & $3.57 \pm 0.08 \mathrm{~b}$ \\
\hline \% Fungi identified to phylum & & \\
\hline Ascomycota & $51.85 \pm 1.87 \mathrm{~b}$ & $63.36 \pm 2.09 \mathrm{a}$ \\
Basidiomycota & $23.78 \pm 1.89$ & $19.35 \pm 1.80$ \\
Zygomycota & $16.8 \pm 0.99 \mathrm{a}$ & $12.8 \pm 1.14 \mathrm{~b}$ \\
Glomeromycota & $1.44 \pm 0.12 \mathrm{a}$ & $0.49 \pm 0.05 \mathrm{~b}$ \\
Chytridiomycota & $0.29 \pm 0.05$ & $0.22 \pm 0.09$ \\
Unclassified fungi & $4.06 \pm 0.92$ & $3.22 \pm 0.54$ \\
Fungi unidentified & $1.70 \pm 0.43$ & $0.54 \pm 0.14$ \\
\hline
\end{tabular}

Significant differences ( $p<0.05$ on the basis of ANOVAs) between the uninvaded and the invaded site were indicated by different letters.

Of those fungal classes where mean relative abundances were greater than $1 \%$, three showed significant differences between the uninvaded and the invaded site soils on the basis of ANOVAs (Figure 3a). Leotiomycetes were higher on the invaded site ( $p=0.01$, uninvaded $6.36 \%$, invaded $8.59 \%$ ), as were Sordariomycetes (a class that includes many pathogenic species) ( $p=0.044$, uninvaded $10.2 \%$, invaded 15.8\%). On the other hand, the class Zygomycota incertae sedis (dominated here by the order Mortierellales) were more abundant on the uninvaded site $(p=0.033$, uninvaded $16.9 \%$, invaded 12.9\%). The uninvaded and invaded sites had 798 and 591 distinct OTUs in each group, respectively, whereas they shared 968 OTUs in common (Figure 3b).

SIMPER analysis was undertaken to identify species and OTUs having the most influence on the separation of the communities (Table 3). An undefined Archaeorhizomyces species was identified as having the greatest effect on dissimilarity between the two sites. This group has been identified by Rosling et al. [38] as ubiquitous in soils and roots, although they do not seem to form recognised mycorrhizal structures. Two OTUs (OTU8 and OTU20) unidentified in the UNITE database were virtually absent from the invaded site. BLAST (Basic Local Alignment Search Tool) analysis against the NCBI database revealed that OTU8 has a high similarity to an uncultured Mortierella clone from arable soils ( $98 \%$ ID; $\mathrm{E}=3 \mathrm{e}^{-129}$ ) and the closest named match to OTU20 is a Clavariaceae sequence from grassland soils $\left(94 \% \mathrm{ID} ; \mathrm{E}=1 \mathrm{e}^{-113}\right)$. Humicola nigrescens was widespread and was eightfold more abundant in the invaded site. 
a

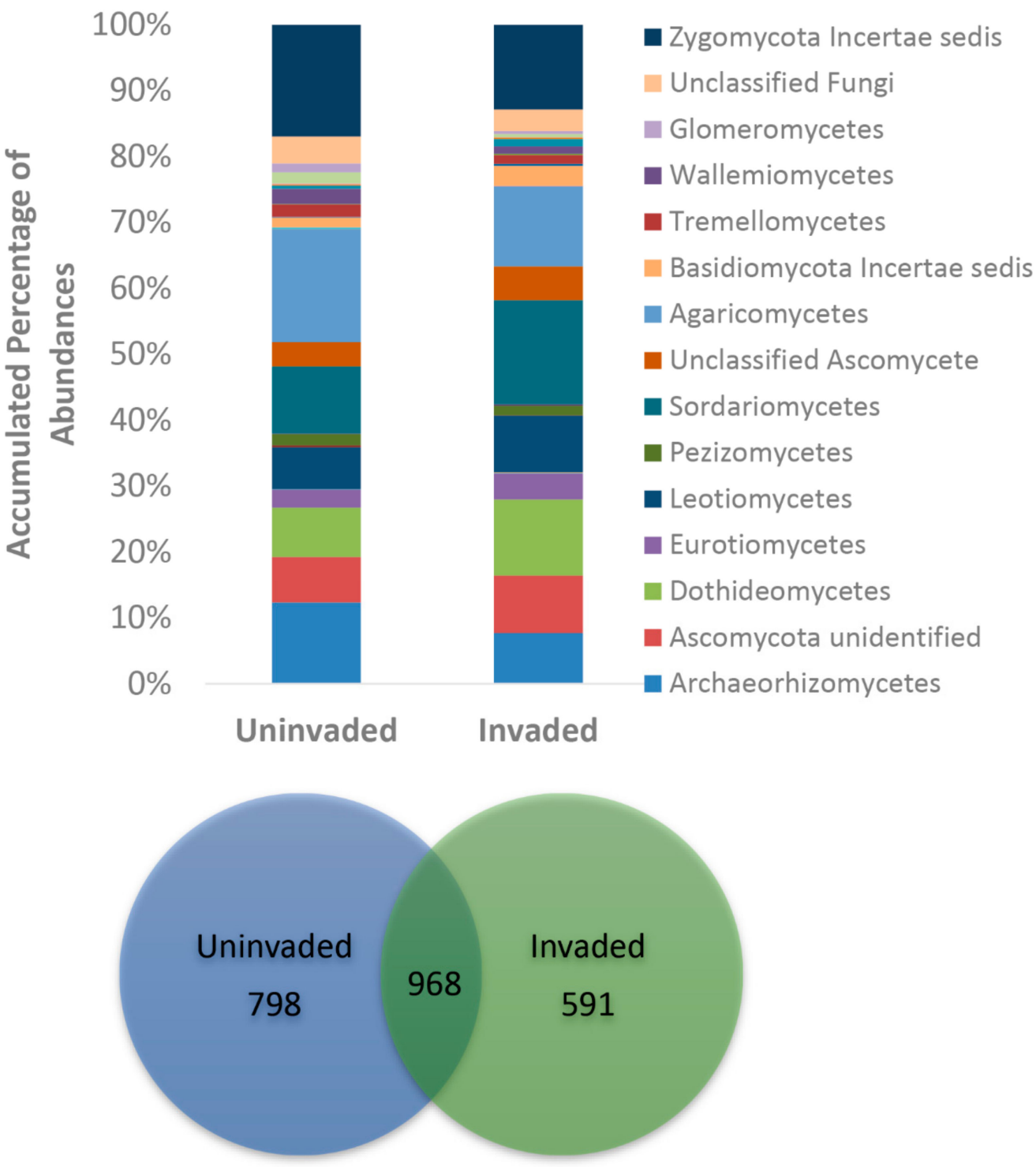

Figure 3. Class level differences (a) in mean \% relative abundances and (b) Venn diagram of assigned OTUs (b) between the two ( $n=25$ each) sites.

Table 3. SIMPER analysis for 10 species contributing most to the dissimilarity $(25.16 \%)$ between the two sites ( $n=25$ each). Av.Ab: average abundance; Av.Di: average dissimilarity; Diss/SD: dissimilarity/standard deviation; Contr\%: contribution to the observed dissimilarity, $\%$ of total; Cum. $\%$ : cumulative contribution $\%$.

\begin{tabular}{|c|c|c|c|c|c|c|c|}
\hline Species & UNITE SH ID & $\begin{array}{c}\text { Uninvaded } \\
\text { Av.Ab }\end{array}$ & $\begin{array}{c}\text { Invaded } \\
\text { Av.Ab }\end{array}$ & Av.Di & Diss/SD & Contr $\%$ & Cum.\% \\
\hline Archaeorhizomyces sp. & SH197151.06FU & $7.86 \%$ & $6.55 \%$ & 5.14 & 0.93 & 6.52 & 6.52 \\
\hline Mortierella sp. & SH211066.06FU & $4.28 \%$ & $4.83 \%$ & 2.32 & 1.13 & 2.94 & 9.46 \\
\hline Mortierella polygonia & SH211068.06FU & $4.59 \%$ & $3.24 \%$ & 2.26 & 1.03 & 2.87 & 12.33 \\
\hline Sordariomycetes OTU 12 & & $1.60 \%$ & $2.33 \%$ & 1.69 & 0.38 & 2.15 & 14.48 \\
\hline Mortierellales OTU 8 & & $3.36 \%$ & $0.01 \%$ & 1.68 & 1.28 & 2.13 & 16.61 \\
\hline Ascomycota sp. & SH209335.06FU & $1.63 \%$ & $2.64 \%$ & 1.42 & 0.75 & 1.80 & 18.41 \\
\hline Humicola nigrescens & SH234919.06FU & $0.37 \%$ & $2.97 \%$ & 1.40 & 0.82 & 1.78 & 20.19 \\
\hline Wallemia sp. & SH230273.06FU & $2.31 \%$ & $1.14 \%$ & 1.39 & 0.41 & 1.76 & 21.95 \\
\hline Hygrocybe sp. & SH190651.06FU & $1.34 \%$ & $1.50 \%$ & 1.29 & 0.47 & 1.64 & 23.59 \\
\hline Agaricales OTU 20 & & $2.47 \%$ & $0.00 \%$ & 1.23 & 0.48 & 1.57 & 25.16 \\
\hline
\end{tabular}


In addition to individual species, the attribution of ecological function to particular clades within the UNITE database allowed the relative abundance of functional guilds (as defined by FUNGuild) to be assessed. Arbuscular mycorrhizal fungi (phylum Glomeromycota) were more abundant on the uninvaded site $(1.44 \%$ vs. $0.49 \%, p<0.001)$, whereas fungi classed as phytopathogenic were more common in the invaded soils (5.93\% vs. $3.09 \%, p=0.003)$ (Figure 4 ).

a

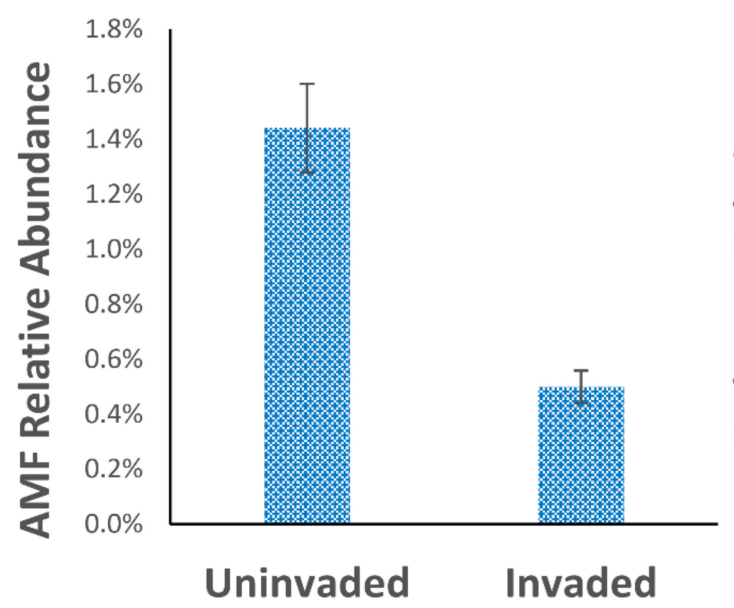

b

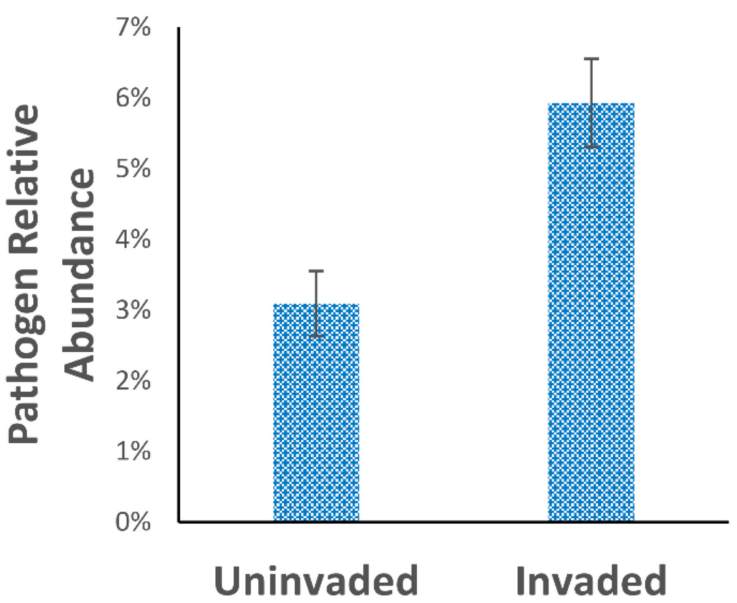

Figure 4. Differences between high level functional groups: (a) arbuscular mycorrhiza $(p<0.001)$; (b) pathogens $(p=0.003)$ on the basis of ANOVA ( $n=25$ per site). Error bars represent SEM (standard error of mean).

\subsection{Fungal-Soil and S. chamaejasme Interrelationships}

The dbRDA analyses investigated whether soil factors were associated with differences in global fungal communities between the invaded and uninvaded sites (Figure 5). Then fungal composition was related to $S$. chamaejasme and to edaphic factors in the invaded site alone, in order to determine whether factors explaining variations within the invaded site were consistent with those differentiating sites (Figure 6). The separation of the fungal communities between the two sites was primarily along axis 1 and most closely linked to soil organic matter (OM), with higher levels of OM on the uninvaded soils (Figure 5). Within the invaded site, fungal composition varied on both axes with a wider range of soil parameters influencing this distribution; neither $S$. chamaejasme abundance nor cover were linked closely to variations in this composition (Figure 6). Indeed there was little pattern to the distribution of fungal communities; no strong link was found between measured soil parameters in these communities, and the proportion of the total variation accounted for in these analyses was very low.

Fungal community composition on the invaded site was further investigated by analysis of the relative abundance of particular species. Variation in this composition was then linked to potential drivers (edaphic and S. chamaejasme) (Figure 7). In some cases, there was a clear negative or positive association with nutrient fertility (e.g., Archaeorhizomyces sp. and Agaricomycetes sp. respectively). Several other species showed a negative correlation with S. chamaejasme coverage, notably Ascomycota sp., Wallemia sp. (xerophilic), and Mortierella sp. (saprotrophic), and a few a positive correlations, for example, Corynespora sp. (plant pathogen). Interestingly, several of the species identified in the SIMPER analysis (Table 3) as contributing most to the dissimilarity between sites were related to the variation in either soil parameters or S. chamaejasme cover (Figure 7) on the invaded site. 


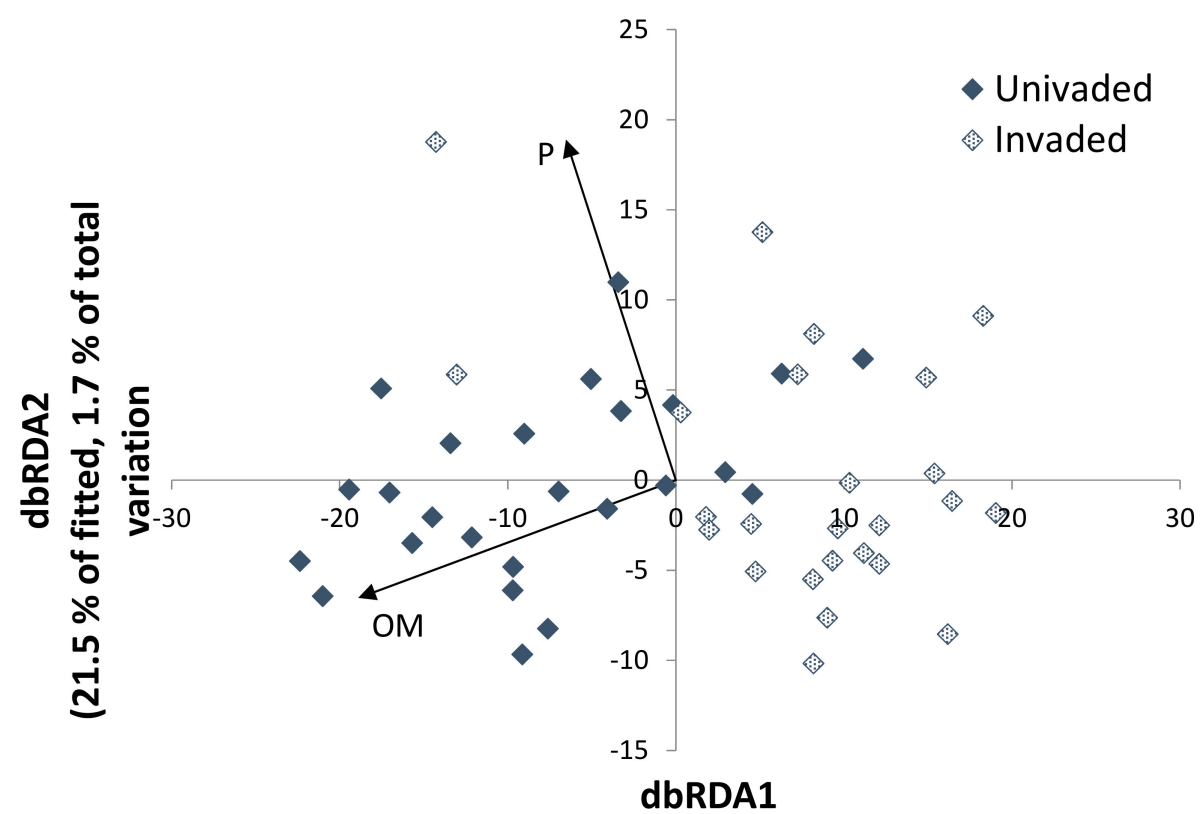

$78.5 \%$ of fitted, $6.3 \%$ of total variation)

Figure 5. Plot relating fungal populations to soil parameters differentiating uninvaded and invaded sites. Of the parameters measured, only percentage total phosphorous and organic matter showed a significant correlation with fungal community composition $(p<0.01, n=25$ per site). dbRDA: distance-based redundancy analysis.

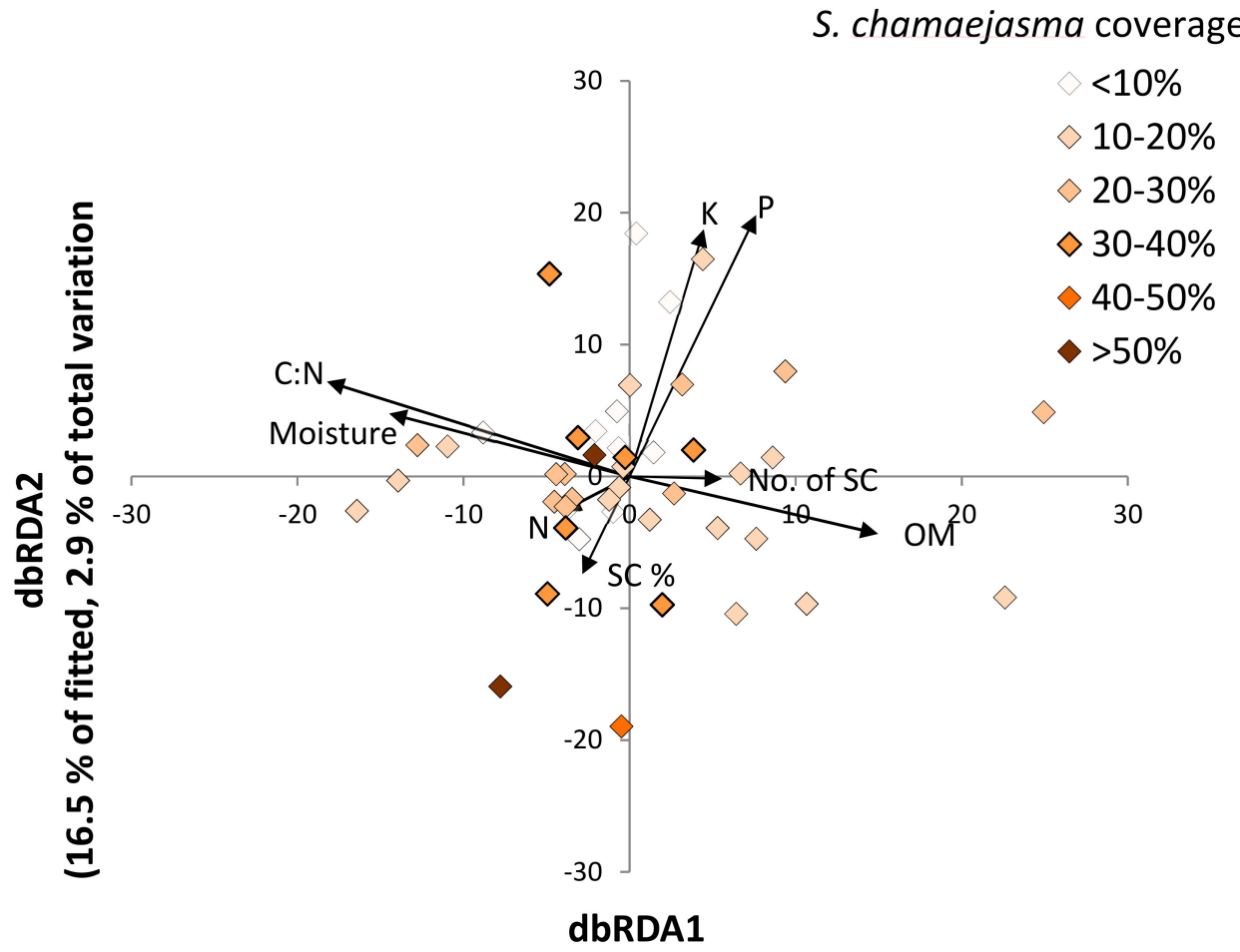

(18\% of fitted, $3.2 \%$ of total variation)

Figure 6. dbRDA plot of global fungal communities in the invaded site $(n=46)$ relating variations in fungal populations with soil and S. chamaejasme cover and abundance. Invaded site only. Nutrient, moisture and organic matter are $\%$ total $(\mathrm{C}=$ carbon, $\mathrm{N}=$ nitrogen, $\mathrm{P}=$ phosphorous, $\mathrm{K}=$ potassium, moisture, and $\mathrm{OM}=$ organic matter). SC $=\%$ cover and abundance of $S$. chamaejasme per quadrat; No. of SC = number of $S$. chamaejasme per quadrat. 


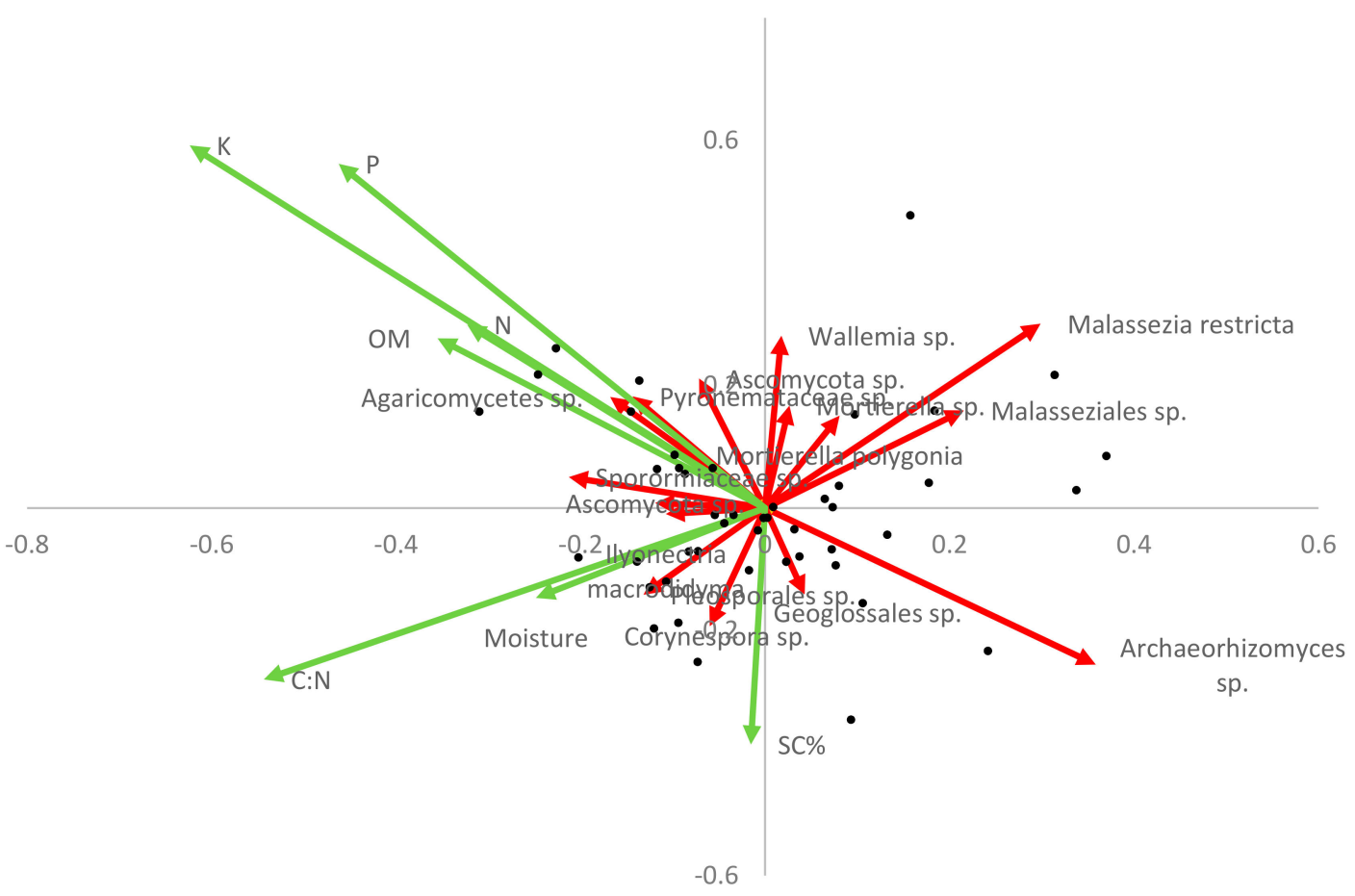

Figure 7. Redundancy analysis triplot of fungal species relative abundance (red) and potential predictive factors (green) for invaded site only $(n=46)$. Only those species most closely correlated with the primary axes were included. Nutrient, moisture, and organic matter are $\%$ total $(\mathrm{N}=$ nitrogen, $\mathrm{P}=$ phosphorous, $\mathrm{K}=$ potassium, moisture, and $\mathrm{OM}=$ organic matter). $\mathrm{SC} \%=\%$ cover.

\section{Discussion}

Our study involved a comparison of two sites only, and thus outcomes in relation to potential influences of edaphic and S. chamaejasme factors on fungal populations were considered substantive only if the importance of site factors as potential drivers of fungal diversity was corroborated by evidence of similar relationships between these factors and fungi on the invaded site. The broad composition of the fungal communities, including the dominance of Ascomycota (greater on the invaded site) and Basidiomycota, and the small component as Glomeromycota were consistent with the findings of Jin et al. [26] who generated clone libraries from rhizosphere soil and root samples of S. chamaejasme from the Tibetan plateau.

In this paper, we found distinctive fungal communities in the grasslands where S. chamaejasme was present, suggesting that either the fungal community of the uninvaded site was inherently different from the invaded site prior to invasion or that the community at the invaded site had been altered by S. chamaejasme. Gibbons et al. [22] found the latter to be the case in an extensive investigation of the microbial communities associated with three invasive weeds of North American prairie grasslands. Here, we did not find the correlation within the invaded site between the overall fungal community and density of $S$. chamaejasme, which might have been expected if $S$. chamaejasme was driving change at this level. However, correlations between vegetation cover and overall fungal composition are often weak [39]. Nevertheless, there was some evidence that $S$. chamaejasme may affect specific rather than total fungal community indices, as some species differentiating the two sites appeared to be related to S. chamaejasme coverage within the invaded site, whereas others were linked more closely to variations in soil organic matter and nutrient fertility rather than S. chamaejasme coverage.

The site differentiation in functional groups, such as arbuscular mycorrhizal fungi (AMF) and fungal pathogens, may explain in part interactions between $S$. chamaejasme and co-occurring species. In plant communities, rare indigenous species may experience more negative feedback from pathogens compared with invasive species [40]. Invaded soils had higher relative abundance of fungal pathogens; 
if flavonoids in S. chamaejasme protect the plant from these pathogens, as suggested by Yan et al. [10], this might provide a competitive advantage over co-occurring species in soils where pathogen occurrence is high.

The relationship between plants and AMF is a complex one and may not always benefit the plant, with the potential of AMF to 'cheat' on their hosts [41]. In an environment where a plant species is invading native species' habitats, AMF have been shown to facilitate both the invasion $[42,43]$ and the ability of native plants to withstand invasion [44,45]. The impact on AMF is likely dependent on a number of factors such as soil nutrient status, host specificity, and the species of AMF present [46]. In addition to their nutritional role, AMF are also implicated in defence against plant pathogenic fungi $[47,48]$, either by occupancy of infection loci [49] or by modification of host defence systems [50,51]. Thus, the increased pathogen presence on the invaded site may be linked at least partly to reduced AMF levels. The higher relative abundance of AMF on the uninvaded site may thus contribute to the ability of plants in this site to withstand invasion. Evidence also suggests that $S$. chamaejasme are only rarely infected with AMF $[25,26]$, indicating that the different levels of AMF abundance may also relate to cover of this species.

Given the lower total P concentrations in invaded soils, this might have been expected to favour Glomeromycota [52], but the opposite was the case, at least in terms of relative abundance (Figure 4). Humicola nigrescens, which produces phytase enzymes for the mobilisation of $\mathrm{P}$ [53], was more abundant in the invaded site, possibly driven by the lower P reserves in these soils. In uninvaded soils, the higher abundance of Zygomycota, and particularly Mortierellales, may be linked to AMF abundance, as they mobilise inorganic P via secretion of organic acids, and act synergistically with AMF [54,55]. In addition, species from the genus Mortierella have recently been shown to colonise roots, promote growth, and prevent disease in Arabidopsis [56].

Root exudates of $S$. chamaejasme inhibit the growth of seedlings across a range of grass and broad-leaved species co-occurring on these grassland soils [2,9]. Whilst bacterial [24] and fungal [57] communities associated with the $S$. chamaejasme rhizosphere have been investigated in several studies, there is no direct evidence of allelopathic effects on soil microbial populations. However, given the evidence of the widespread bioactive nature of chemicals derived from $S$. chamaejasme, including some with nematicidal properties [58] and activity against phytopathogenic fungi [27], direct effects of root chemicals on soil microflora might have been expected. Our findings suggest that soil chemical characteristics (organic content in particular) rather than S. chamaejasme factors are the stronger predictor of variation in overall fungal populations. Therefore, if root exudates from $S$. chamaejasme have any effects on fungal composition, these are probably restricted to certain components of the populations.

Given that S. chamaejasme sequences were detected in uninvaded soils, where this species was not recorded, the absence of established S. chamaejasme was likely due to soil factors rather than restricted sources of propagules. There were multiple differences in soil physiochemical parameters between sites, mostly indicative of higher soil fertility in the uninvaded site. Soil organic matter and nutrient fertility were also linked to several functional groups of fungi. However, it is likely that at least some of the soil site differences existed prior to invasion given the scale of these differences and the low above-ground annual production $\left(1.6 \mathrm{tha}^{-1}\right)$ typical of these pastures [59]. Organic matter increases have been attributed to $S$. chamaejasme in a previous study [11], but here lower organic matter concentrations were found in the invaded soils. Using bulk density values for similar grasslands [31], differences between sites in soil organic stocks to $20 \mathrm{~cm}$ depth were calculated to be approximately 43 tha $^{-1}$, equivalent to an average annual loss in excess of 2.1 tha $^{-1}$ over the 20 years since invasion was first noted. Other differences, such as those in $\mathrm{N}$ and $\mathrm{P}$, are likely to relate organic matter trends.

The lower C:N ratio in invaded soils is consistent with the findings of Sun et al. [11], who suggested S. chamaejasme may impact the quality of organic matter. The occurrence of legumes in the invaded site was considered too low to have a substantive effect on this ratio. Lower C:N ratios may also indicate higher rates of $C$ mineralisation in invaded soils, consistent with data in Table 1 and also the findings of Sun et al. [11]. Overall, it seems likely that the invaded site was more susceptible to 
ingress by $S$. chamaejasme due to its lower soil fertility, leading to the indigenous plant community being less competitive, rather than $S$. chamaejasme driving such changes with consequent effects on soil fungal communities. A previous study [28] demonstrated that higher surface soil moisture $(0-10 \mathrm{~cm})$ favoured grass species competition with S. chamaejasme; this was not supported by our findings, but moisture levels may have been affected by rainfall prior to sampling.

\section{Conclusions}

The main aim of this research was to investigate potential interactions between $S$. chamaejasme and soil fungi. In terms of total fungal community composition, the evidence for any such interactions was limited. There was, however, evidence of potential influences on particular functional groups and individual species. Whether any such plant-fungal interactions contribute to invasion success is unclear, but our findings suggest the need for further research under controlled experimental conditions to explore this relationship. In addition to potential plant-fungal feedbacks, results reported here suggest that lower inherent soil fertility may be an important factor affecting the susceptibility of grassland systems to $S$. chamaejasme ingress and persistence. Soil moisture, in particular subsoil reserves [28], are also likely to alter competition between indigenous species and the deeper rooting S. chamaejasme. Other factors such as over-grazing, with selective herbivory and increased trampling, are known drivers of invasion.

Author Contributions: Conceptualization, W.H. and J.S.; Software, A.D.; Validation, W.H., Y.L., A.D., and J.S.; Formal analysis, A.D., W.H., Y.L., and H.W.; Resources, Y.L. and L.W.; Writing, J.S., W.H., A.D., and G.W.G.; Visualization, A.D.; Supervision, Y.W.; Funding acquisition, W.H. and Y.W.

Funding: This work was supported by the National Natural Science Foundation of China (31402133), Special Aid Fund for Qinghai Province (2020-QY-210), and Key Laboratory Research Fund of Department of Education of Shaanxi Province (18JS110) to W.H.; National Natural Science Foundation of China (41871335) to Y.L.; Special Fund for Agro-scientific Research in the Public Interest of China (201203062) to Y.W., W.H., and J.S. We acknowledge the support of a Stapledon Fellowship and BBSRC (Biotechnology and Biological Sciences Research Council) exchange grant BB/M027945/1, which helped in the formation of this manuscript. A.D. is supported by the WEFO/ERDF (Welsh European Funding Office/European Regional Development Fund) funded Flexis project.

Conflicts of Interest: The authors declare no conflict of interest. The funders had no role in the design of the study; in the collection, analyses, or interpretation of data; in the writing of the manuscript, or in the decision to publish the results.

\section{References}

1. Zhang, Y.H.; Volis, S.; Sun, H. Chloroplast phylogeny and phylogeography of Stellera chamaejasme on the Qinghai-Tibet Plateau and in adjacent regions. Mol. Phylogenet. Evol. 2010, 57, 1162-1172. [CrossRef] [PubMed]

2. Guo, H.R.; Zeng, L.M.; Yan, Z.Q.; Jin, H.; Li, X.Z.; Guan, J.F.; Qin, B. Allelochemical from the root exudates of Stellera chamaejasme L. and its degradation. Allelopath. J. 2016, 38, 119-190.

3. Zhao, M.L.; Gao, X.L.; Wang, J.; He, X.L.; Han, B. A review of the most economically important poisonous plants to the livestock industry on temperate grasslands of China. J. Appl. Toxicol. 2013, 33, 9-17. [CrossRef]

4. Ren, G.; Shang, Z.; Long, R.; Hou, Y.; Deng, B. The relationship of vegetation and soil differentiation during the formation of black-soil-type degraded meadows in the headwater of the Qinghai-Tibetan Plateau, China. Environ. Earth Sci. 2013, 69, 235-245. [CrossRef]

5. Xie, Y.Z.; Wittig, R. Growth parameters of characteristic species of Stipa steppes in Northern China as indicators of the grazing intensity. J. Appl. Bot. Angew. Bot. 2003, 77, 68-74.

6. Klein, J.A.; Harte, J.; Zhao, X.-Q. Experimental warming, not grazing, decreases rangeland quality on the Tibetan Plateau. Ecol. Appl. 2007, 17, 541-557. [CrossRef] [PubMed]

7. Leng, X.; Cui, J.; Zhang, S.T.; Zhang, W.G.; Liu, Y.H.; Liu, S.R.; An, S.Q. Differential water uptake among plant species in humid alpine meadows. J. Veg. Sci. 2013, 24, 138-147. [CrossRef]

8. Guo, H.; Cui, H.; Jin, H.; Yan, Z.; Ding, L.; Qin, B. Potential allelochemicals in root zone soils of Stellera chamaejasme L. and variations at different geographical growing sites. Plant Growth Regul. 2015, 77, 335-342. [CrossRef] 
9. Pan, L.; Li, X.Z.; Yan, Z.Q.; Guo, H.R.; Qin, B. Phytotoxicity of umbelliferone and its analogs: Structure-activity relationships and action mechanisms. Plant Physiol. Biochem. 2015, 97, 272-277. [CrossRef]

10. Yan, L.F.; Xu, C.; Liu, Q.; Gu, A.H.; Jiang, Z.Y. Altered profile of gut microbiota after subchronic exposure to neochamaejasmin A in rats. Environ. Toxicol. Pharm. 2015, 39, 927-933. [CrossRef]

11. Sun, G.; Luo, P.; Wu, N.; Qiu, P.; Gao, Y.; Chen, H.; Shi, F. Stellera chamaejasme L. increases soil N availability, turnover rates and microbial biomass in an alpine meadow ecosystem on the eastern Tibetan Plateau of China. Soil Biol. Biochem. 2009, 41, 86-91. [CrossRef]

12. Callaway, R.M.; Thelen, G.C.; Rodriguez, A.; Holben, W.E. Soil biota and exotic plant invasion. Nature 2004, 427, 731. [CrossRef] [PubMed]

13. Maron, J.L.; Klironomos, J.; Waller, L.; Callaway, R.M. Invasive plants escape from suppressive soil biota at regional scales. J. Ecol. 2014, 102, 19-27. [CrossRef]

14. Rout, M.E.; Callaway, R.M. Interactions between exotic invasive plants and soil microbes in the rhizosphere suggest that 'everything is not everywhere'. Ann. Bot. 2012, 110, 213-222. [CrossRef]

15. Xiao, H.F.; Feng, Y.L.; Schaefer, D.A.; Yang, X.D. Soil fungi rather than bacteria were modified by invasive plants, and that benefited invasive plant growth. Plant Soil 2014, 378, 253-264. [CrossRef]

16. Wolfe, B.E.; Rodgers, V.L.; Stinson, K.A.; Pringle, A. The invasive plant Alliaria petiolata (garlic mustard) inhibits ectomycorrhizal fungi in its introduced range. J. Ecol. 2008, 96, 777-783. [CrossRef]

17. North, B.A.; Torzilli, A.P. Characterization of the root and soil mycobiome associated with invasive Microstegium vimineum in the presence and absence of a native plant community. Botany 2017, 95, 513-520. [CrossRef]

18. Jordan, N.R.; Aldrich-Wolfe, L.; Huerd, S.C.; Larson, D.L.; Muehlbauer, G. Soil-occupancy effects of invasive and native grassland plant species on composition and diversity of mycorrhizal associations. Invasive Plant Sci. Manag. 2012, 5, 494-505. [CrossRef]

19. Broz, A.K.; Manter, D.K.; Vivanco, J.M. Soil fungal abundance and diversity: Another victim of the invasive plant Centaurea maculosa. ISME J. 2007, 1, 763. [CrossRef]

20. Gaggini, L.; Rusterholz, H.-P.; Baur, B. The invasive plant Impatiens glandulifera affects soil fungal diversity and the bacterial community in forests. Appl. Soil Ecol. 2018, 124, 335-343. [CrossRef]

21. Si, C.; Liu, X.; Wang, C.; Wang, L.; Dai, Z.; Qi, S.; Du, D. Different degrees of plant invasion significantly affect the richness of the soil fungal community. PLOS ONE 2013, 8, e85490. [CrossRef] [PubMed]

22. Gibbons, S.M.; Lekberg, Y.; Mummey, D.L.; Sangwan, N.; Ramsey, P.W.; Gilbert, J.A. Invasive plants rapidly reshape soil properties in a grassland ecosystem. MSystems 2017, 2, e0178-16. [CrossRef]

23. Cui, H.; Yang, X.; Lu, D.; Jin, H.; Yan, Z.; Chen, J.; Li, X.; Qin, B. Isolation and characterization of bacteria from the rhizosphere and bulk soil of Stellera chamaejasme L. Can. J. Microbiol. 2014, 61, 171-181. [CrossRef] [PubMed]

24. Jin, H.; Yang, X.; Liu, R.; Yan, Z.; Li, X.; Li, X.; Su, A.; Zhao, Y.; Qin, B. Bacterial community structure associated with the rhizosphere soils and roots of Stellera chamaejasme L. along a Tibetan elevation gradient. Ann. Microbiol. 2018, 68, 273-286. [CrossRef]

25. Jin, H.; Yan, Z.; Liu, Q.; Yang, X.; Chen, J.; Qin, B. Diversity and dynamics of fungal endophytes in leaves, stems and roots of Stellera chamaejasme L. in northwestern China. Antonie Van Leeuwenhoek 2013, 104, 949-963. [CrossRef]

26. Jin, H.; Yang, X.; Lu, D.; Li, C.; Yan, Z.; Li, X.; Zeng, L.; Qin, B. Phylogenic diversity and tissue specificity of fungal endophytes associated with the pharmaceutical plant, Stellera chamaejasme L. revealed by a cultivation-independent approach. Antonie Van Leeuwenhoek 2015, 108, 835-850. [CrossRef] [PubMed]

27. Shi, G.; Tao, K.; Zhou, W.; Hou, T. Isolation of antifungal compound against phytophthora infestans from Stellera chamaejasme L. Asian J. Chem. 2013, 25, 4058-4060. [CrossRef]

28. Deng, J.; Zhu, Z. Research of Stelleara chamaejasme community characteristics in Qilian County and the relationship between them and the soil moisture of different depth. China Popul. Resour. Environ. 2014, 24, 168-170.

29. Kang, L.; Han, X.G.; Zhang, Z.B.; Sun, O.J. Grassland ecosystems in China: Review of current knowledge and research advancement. Philos. Trans. R. Soc. B 2007, 362, 997-1008. [CrossRef]

30. Zhou, W.; Yang, H.; Huang, L.; Chen, C.; Lin, X.S.; Hu, Z.J.; Li, J.L. Grassland degradation remote sensing monitoring and driving factors quantitative assessment in China from 1982 to 2010. Ecol. Indic. 2017, 83, 303-313. [CrossRef] 
31. Li, X. Study on the Relationship between the Distribution of Stellera chamaejasme and the Soil Properties Based on GIS. Master's Thesis, Northwest University, Xian, China, 2017.

32. Bao, S.D. Soil Agricultural Chemical Analysis, 3rd ed.; China Agricultural Press: Beijing, China, 2000.

33. Detheridge, A.P.; Brand, G.; Fychan, R.; Crotty, F.V.; Sanderson, R.; Griffith, G.W.; Marley, C.L. The legacy effect of cover crops on soil fungal populations in a cereal rotation. Agric. Ecosyst. Environ. 2016, 228, $49-61$. [CrossRef]

34. Wang, Q.; Garrity, G.M.; Tiedje, J.M.; Cole, J.R. Naive Bayesian classifier for rapid assignment of rRNA sequences into the new bacterial taxonomy. Appl. Environ. Microb. 2007, 73, 5261-5267. [CrossRef] [PubMed]

35. Abarenkov, K.; Henrik Nilsson, R.; Larsson, K.H.; Alexander, I.J.; Eberhardt, U.; Erland, S.; Hoiland, K.; Kjoller, R.; Larsson, E.; Pennanen, T.; et al. The UNITE database for molecular identification of fungi-Recent updates and future perspectives. New Phytol. 2010, 186, 281-285. [CrossRef] [PubMed]

36. Nguyen, N.H.; Song, Z.W.; Bates, S.T.; Branco, S.; Tedersoo, L.; Menke, J.; Schilling, J.S.; Kennedy, P.G. FUNGuild: An open annotation tool for parsing fungal community datasets by ecological guild. Fungal Ecol. 2016, 20, 241-248. [CrossRef]

37. Legendre, P.; Anderson, M.J. Distance-based redundancy analysis: Testing multispecies responses in multifactorial ecological experiments. Ecol. Monogr. 1999, 69, 1-24. [CrossRef]

38. Rosling, A.; Cox, F.; Cruz-Martinez, K.; Ihrmark, K.; Grelet, G.-A.; Lindahl, B.D.; Menkis, A.; James, T.Y. Archaeorhizomycetes: Unearthing an ancient class of ubiquitous soil fungi. Science 2011, 333, 876-879. [CrossRef]

39. Tedersoo, L.; Bahram, M.; Põlme, S.; Kõljalg, U.; Yorou, N.S.; Wijesundera, R.; Ruiz, L.V.; Vasco-Palacios, A.M.; Thu, P.Q.; Suija, A. Global diversity and geography of soil fungi. Science 2014, 346, 1256688. [CrossRef]

40. Klironomos, J.N. Feedback with soil biota contributes to plant rarity and invasiveness in communities. Nature 2002, 417, 67-70. [CrossRef]

41. Jin, L.; Wang, Q.; Wang, Q.; Wang, X.; Gange, A.C. Mycorrhizal-induced growth depression in plants. Symbiosis 2017, 72, 81-88. [CrossRef]

42. Jin, L.; Zhang, G.Q.; Wang, X.J.; Dou, C.Y.; Chen, M.; Lin, S.S.; Li, Y.Y. Arbuscular mycorrhiza regulate inter-specific competition between a poisonous plant, Ligularia virgaurea, and a co-existing grazing grass, Elymus nutans, in Tibetan Plateau Alpine meadow ecosystem. Symbiosis 2011, 55, 29-38. [CrossRef]

43. Nijjer, S.; Rogers, W.E.; Lee, C.-T.A.; Siemann, E. The effects of soil biota and fertilization on the success of Sapium sebiferum. Appl. Soil Ecol. 2008, 38,1-11. [CrossRef]

44. Bary, F.; Gange, A.C.; Crane, M.; Hagley, K.J. Fungicide levels and arbuscular mycorrhizal fungi in golf putting greens. J. Appl. Ecol. 2005, 42, 171-180. [CrossRef]

45. Gange, A.C.; Lindsay, D.E.; Ellis, L.S. Can arbuscular mycorrhizal fungi be used to control the undesirable grass Poa annua on golf courses? J. Appl. Ecol. 1999, 36, 909-919. [CrossRef]

46. Bray, S.R.; Kitajima, K.; Sylvia, D.M. Mycorrhizae differentially alter growth, physiology, and competitive ability of an invasive shrub. Ecol. Appl. 2003, 13, 565-574. [CrossRef]

47. Hooker, J.; Jaizme-Vega, M.; Atkinson, D. Biocontrol of Plant Pathogens Using Arbuscular Mycorrhizal Fungi. In Impact of Arbuscular Mycorrhizas on Sustainable Agriculture and Natural Ecosystems; Springer, Birkhäuser: Basel, Switzerland, 1994; pp. 191-200.

48. Herre, E.A.; Mejía, L.C.; Kyllo, D.A.; Rojas, E.; Maynard, Z.; Butler, A.; Van Bael, S.A. Ecological implications of anti-pathogen effects of tropical fungal endophytes and mycorrhizae. Ecology 2007, 88, 550-558. [CrossRef] [PubMed]

49. Vigo, C.; Norman, J.; Hooker, J. Biocontrol of the pathogen Phytophthora parasitica by arbuscular mycorrhizal fungi is a consequence of effects on infection loci. Plant Pathol. 2000, 49, 509-514. [CrossRef]

50. Liang, M.; Liu, X.; Etienne, R.S.; Huang, F.; Wang, Y.; Yu, S. Arbuscular mycorrhizal fungi counteract the Janzen-Connell effect of soil pathogens. Ecology 2015, 96, 562-574. [CrossRef]

51. Pérez-de-Luque, A.; Tille, S.; Johnson, I.; Pascual-Pardo, D.; Ton, J.; Cameron, D.D. The interactive effects of arbuscular mycorrhiza and plant growth-promoting rhizobacteria synergistically enhance host plant defences against pathogens. Sci. Rep. 2017, 7, 16409. [CrossRef]

52. Zhou, H.S.; Yang, G.W.; Zhang, Y.J. The impact of soil available phosphorus on the AM fungi and the organic acids exudation at different patches in northern steppe of China. J. Anim. Vet. Adv. 2012, 11, 4553-4558. [CrossRef] 
53. Bala, A.; Jain, J.; Kumari, A.; Singh, B. Production of an extracellular phytase from a thermophilic mould Humicola nigrescens in solid state fermentation and its application in dephytinization. Biocatal. Agric. Biotechnol. 2014, 3, 259-264. [CrossRef]

54. Zhang, H.; Wu, X.; Li, G.; Qin, P. Interactions between arbuscular mycorrhizal fungi and phosphate-solubilizing fungus (Mortierella sp.) and their effects on Kostelelzkya virginica growth and enzyme activities of rhizosphere and bulk soils at different salinities. Biol. Fertil. Soils 2011, 47, 543-554. [CrossRef]

55. Zhang, H.S.; Qin, F.F.; Qin, P.; Pan, S.M. Evidence that arbuscular mycorrhizal and phosphate-solubilizing fungi alleviate $\mathrm{NaCl}$ stress in the halophyte Kosteletzkya virginica: Nutrient uptake and ion distribution within root tissues. Mycorrhiza 2014, 24, 383-395. [CrossRef] [PubMed]

56. Johnson, J.M.; Ludwig, A.; Furch, A.; Mithöfer, A.; Scholz, S.S.; Reichelt, M.; Oelmüller, R. The beneficial root-colonizing fungus Mortierella hyalina promotes the aerial growth of Arabidopsis and activates calcium-dependent responses which restrict Alternaria brassicae-induced disease development in roots. Mol. Plant Microbe Interact. 2018, 32, 351-363. [CrossRef] [PubMed]

57. Lu, D.X.; Jin, H.; Yang, X.Y.; Zhang, D.H.; Yan, Z.Q.; Li, X.Z.; Zhao, Y.H.; Han, R.B.; Qin, B. Characterization of rhizosphere and endophytic fungal communities from roots of Stipa purpurea in alpine steppe around Qinghai Lake. Can. J. Microbiol. 2016, 62, 643-656. [CrossRef] [PubMed]

58. Cui, H.; Jin, H.; Liu, Q.; Yan, Z.; Ding, L.; Qin, B. Nematicidal metabolites from roots of Stellera chamaejasme against Bursaphelenchus xylophilus and Bursaphelenchus mucronatus. Pest Manag. Sci. 2014, 70, 827-835. [CrossRef]

59. Sa, W.; An, L. Changes in plant community diversity and aboveground biomass along with altitude within an alpine meadow on the Three-River source region. Chin. Sci. Bull. 2012, 57, 3573-3577. [CrossRef]

(C) 2019 by the authors. Licensee MDPI, Basel, Switzerland. This article is an open access article distributed under the terms and conditions of the Creative Commons Attribution (CC BY) license (http://creativecommons.org/licenses/by/4.0/). 